\title{
PERKOSAAN SEBAGAI ALASAN PENCABUTAN KEKUASAAN WALI DALAM PERKAWINAN
}

\author{
Fakhruddin dan Ramadhita \\ Fakultas Syariah UIN Maulana Malik Ibrahim Malang \\ Email: dhita_rama@yahoo.com Hp.085648708718
}

\begin{abstract}
Abstrak
This research aims at describing the illigibility indicators of marital guardians based on Islamic marital law and common law perspective and its disenfranchisement due to rape and violence towards daughters. This research applies statute and comparative approach. The result reveals that there is a similarity between common law and Islamic marital law relating to religion and maturity backgrounds. Disenfranchisement can be implemented only for custody through court procedure. However, it is not related to guardian's authority in marriage, to some extent Islamic marital law gives chance to implement disenfranchisement due to rape and violence on those who are under guardians' authority.

Penelitian ini bertujuan untuk mendeskripsikan tinjauan figh munakahat dan hukum positif terhadap indikator kelayakan seorang wali dalam perkawinan, dan pencabutan hak kewalian dalam pernikahan karena melakukan perkosaan dan kekerasan pada anak perempuannya. Penelitian ini menggunakan pendekatan perundang-undangan (statute approach) dan perbandingan (comparative approach). Hasil penelitian menunjukkan adannya persamaan antara figh munakahat dan peraturan perundang-undangan dalam menentukan kelayakan wali untuk perkawinan terkait dengan latar belakang agama dan aspek kedewasan. Pencabutan kekuasaan wali dalam konteks peraturan perundangundangan hanya berkaitan dengan kuasa asuh orang tua melalui prosedur pengadilan dan tidak berlaku untuk kekuasaan wali dalam perkawinan, sedangkan figh munakahat memberikan peluang pencabutan kekuasaan wali dalam perkawinan jika wali melakukan kekerasan bahkan perkosaan terhadap orang yang berada di bawah perwaliannya.
\end{abstract}

Kata Kunci: Wali Perkawinan, Pencabutan Hak, Perkosaan

Kekerasan telah menjadi salah satu cara yang dipilih oleh sebagian orang atau kelompok untuk mensikapi dan menyelesaikan suatu persoalan. Berbagai konflik bernuansa ras, agama, kepercayaan, ekonomi, politik, budaya, bahkan nasionalisme mengarah pada sebuah perilaku anarkis. Pelakunya bukan hanya dari kalangan masyarakat awam, melainkan juga kelompokkelompok intelektual, public figure, atau para elit politik yang dipandang memiliki prestise yang lebih. Ironisnya, kekerasan tidak ha- nya terjadi di wilayah publik, tetapi telah menjalar ke dalam ranah-ranah domestik. Tidak jarang dijumpai kasus kekerasan yang dilakukan oleh salah satu anggota keluarga terhadap anggota keluarga yang lain, setidaknya dalam kurun waktu dua dekade belakangan ini.

Kekerasan di wilayah domestik masih saja menjadi persoalan yang tabu untuk dibicakan atau dilakukan proses hukum terhadap pelakunya, meskipun jumlahnya terus mengalami peningkatan tiap tahunnya dan 
masih banyak kasus KDRT(Kekerasan Dalam Rumah Tangga) yang tidak dilaporkan (black number). Salah satu varian kekerasan terhadap perempuan yang dinilai memprihatinkan, baik jumlah maupun penanganannya, yaitu kekerasan seksual. Menurut LBH APIK, sebanyak 144 kasus kasus perkosaan pada tahun 2005, sebanyak 37 kasus diantaranya dilakukan oleh paman, ayah kandung, anak kandung, ayah tiri, kakak tiri, kakek tiri, kakek kandung; 106 kasus lainnya dilakukan oleh orang yang dikenal korban seperti tetangga, guru, ustadz, teman, pacar, dukun, dokter, tukang ojek langganan, tukang bakso langganan; dan 17 kasus lainnya dilakukan oleh orang yang baru kenal korban. Selain itu, sebanyak 16 kasus pelakunya sama sekali tidak dikenal korban, dan 9 kasus di antaranya tidak diketahui korban. ${ }^{1}$

Sepanjang tahun 2006, LBH APIK Jakarta juga melakukan pendampingan hukum terhadap 24 kasus kekerasan seksual, dengan perincian 4 kasus pelecehan seksual, 4 kasus pencabulan 15 kasus perkosaan dan 1 kasus percobaan perkosaan. Pelaku sebagian besar adalah orang yang dikenal baik korban, seperti orang tua, kakak, adik, kakek, paman, tetangga, teman bermain, pacar, majikan, dukun, guru, guru ngaji, tukang ojek langganan. Dan sisanya dilakukan oleh orang yang sama sekali tidak dikenal oleh korban. ${ }^{2}$

Komnas Perempuan mencatat, antara tahun 2010-2011, ditemukan sebanyak 105.103 kasus kekerasan terhadap perempuan dan 3.753 kasus di antaranya adalah kekerasan seksual, seperti perkosaan, eksploitasi seksual, pelecehan seksual, kontrol seksual. Ironisnya, pelaku kejahatan adalah orang yang memiliki hubungan darah dengan korban seperti ayah, kakak, adik, paman, kakek, atau hubungan kekerabatan, suami maupun pacar korban. Kejahatan terhadap perempuan juga

${ }^{1} \mathrm{LBH}$ APIK, Pemiskinan Perempuan dan Upaya Setengah Hati Negara dalam Menegakkan Hak Asasi Perempuan, (Online), (http://www.lbh-apik.or.id/ catahu\%202005.htm, diakses tanggal 11 Juni 2011)

${ }^{2}$ LBH APIK, Perjuangan Berat Perempuan Indonesia Menggapai Keadilan di Tengah Berbagai Keterpurukan, (Online), (http://www.lbh-apik.or.id/catahu\%202006. htm, diakses tanggal 11 Juni 2011) dilakukan oleh majikan, tetangga, guru, teman sekerja, tokoh masyarakat, ataupun orang yang tidak dikenal. ${ }^{3}$

Kekerasan seksual yang dilakukan oleh keluarga dekat korban perlu mendapat perhatian lebih dari berbagai pihak. Sebab secara sosiologis, keluarga memiliki berbagai fungsi dan salah satunya adalah fungsi protektif. ${ }^{4}$ Menurut Djuju Sudjana sebagaimana dikutip oleh Mufidah, keluarga berfungsi sebagai tempat yang aman dari gangguan internal maupun eksternal, serta menangkal segala pengaruh negatif yang masuk ke dalamnya. ${ }^{5}$

Secara yuridis, orang tua memiliki sejumlah kewajiban terhadap anak-anaknya. Pasal 9 Undang-Undang Nomor 4 Tahun 1979 tentang Kesejahteraan Anak menyatakan bahwa orang tua adalah yang pertama-tama bertanggungjawab atas terwujudnya kesejahteraan anak baik secara rohani, jasmani maupun sosial. ${ }^{6}$ Ketentuan ini dipertegas dalam Pasal 13 ayat (1) Undang-Undang Nomor 23 Tahun 2002 tentang Perlindungan Anak yang menyatakan bahwa setiap anak selama dalam pengasuhan orang tua, wali, atau pihak lain manapun yang bertanggung jawab atas pengasuhan, berhak mendapat perlindungan dari perlakuan: (a) diskriminasi; (b) eksploitasi, baik ekonomi maupun seksual; (c) penelantaran; (d) kekejaman, kekerasan, dan penganiayaan; (e) ketidakadilan; dan (f) perlakuan salah lainnya. ${ }^{7}$

Hukum Islam yang terkodifikasi dalam figh, bahkan memposisikan beberapa anggota keluarga sebagai wali yang menentukan sahnya suatu perkawinan. Para fuqaha, juga

\footnotetext{
${ }^{3}$ Sahat Tarida, Kekerasan Seksual dalam Catatan Tahunan Komnas Perempuan Tahun 2011, (Online), (http://www.komnasperempuan.or.id/2011/08/ kekerasan-seksual-dalam-catatan-tahunan-komnasperempuan-tahun-2011/, diakses tanggal 08 September 2011)

${ }^{4}$ Mufidah Ch., Psikologi Keluarga Islam Berwawasan Gender (Malang: UIN-Malang Press,2008), h. 42

${ }^{5}$ Mufidah Ch., Psikologi....., h. 45

${ }^{6}$ Undang-Undang Nomor 4 Tahun 1979 tentang Kesejahteraan Anak LN. Tahun 1979 Nomor 32

${ }^{7}$ Undang-Undang Nomor 22 Tahun 2002 tentang Perlindungan Anak LN. Tahun 2002 Nomor 109
} 
memberikan hak khusus bagi wali seperti hak ijbar dan hak fasakh, yang tentunya melalui mekanisme Pengadilan Agama. Persoalan wali nikah telah ditransformasikan ke dalam peraturan perundang-undangan. Secara tegas, dalam Pasal 19 Kompilasi Hukum Islam, memposisikan wali sebagai rukun yang harus dipenuhi oleh calon mempelai wanita. Bahkan, Ayah kandung yang tidak penah melaksanakan fungsinya sebagai kepala keluarga tidak gugur hak kewaliannya untuk mencegah perkawinan yang akan dilakukan oleh wali nikah yang lain. ${ }^{8}$

Dimensi normatif ini dalam kurun waktu belakangan ini dihadapkan pada realitas bahwa seorang wali melakukan perbuatan yang secara moral maupun hukum menciderai rasa kemanusiaan dan keadilan, karena melakukan kekerasan fisik, psikis, bahkan perkosaan terhadap anak kandungnya, atau orang yang berada di bawah perwaliannya. Pertanyaannya kemudian, masihkah ia dinyatakan layak menjadi seorang wali? Sedangkan dalam Pasal 5 Undang-Undang Nomor 23 Tahun 2004 tentang Penghapusan Kekerasan Dalam Rumah Tangga ditegaskan bahwa setiap orang dilarang melakukan kekerasan dalam rumah tangga terhadap orang dalam lingkup rumah tangganya, dengan cara : (a) kekerasan fisik; (b) kekerasan psikis; (c) kekerasan seksual; atau (d) penelantaran rumah tangga.

Berdasarkan kontradiksi ini, tujuan penelitian ini adalah: (1) Mendeskripsikan tinjauan fiqh munakahat dan hukum positif terhadap indikator kelayakan seorang wali dalam perkawinan, (2) Mendeskripsikan pencabutan hak kewalian dalam pernikahan karena melakukan perkosaan dan kekerasan pada anak perempuannya dalam perspektif fiqh munakahat dan hukum positif

Tulisan ini merupakan hasil penelitian kepustakaan (library reseach) yang berupaya membandingkan ketentuan perwalian dalam fiqh munakahat dan peraturan perun-

\footnotetext{
${ }^{8}$ Kompilasi Hukum Islam disebarluaskan melalui Instruksi Presiden Nomor 1 Tahun 1991
}

dang-undangan yang mengarah pada kemungkinan pencabutan kekuasaan wali dalam perkawinan karena melakukan perkosaan terhadap anak perempuan yang berada di bawah kekuasaannya.

Istilah perkosaan menurut Soetandyo Wignjosoebroto, adalah suatu usaha melampiaskan nafsu seksual oleh laki-laki terhadap perempuan dengan cara yang dianggap melanggar menurut moral dan hukum. Sedangkan R. Sugandhi, menyatakan bahwa perkosaan adalah seorang pria memaksa pada wanita bukan istrinya untuk melakukan hubungan biologis dengan ancaman kekerasan.

PAF Lamintang dan Djisman Samosir mengatakan bahwa perkosaan adalah perbuatan seseorang yang dengan kekerasan atau ancaman kekerasan memaksa seorang wanita untuk melakukan hubungan biologis di luar perkawinan dengan dirinya. Berdasarkan definisi ini dapat diketahui bahwa, dalam suatu perkosaan harus dapat dibuktikan adanya unsur kekerasan atau ancaman. Selain itu, dalam definisi ini tidak meliputi marital rape karena ruang lingkup perkosaan sendiri harus terjadi luar perkawinan yang sah. ${ }^{9}$

Secara yuridis, perkosaan diatur dalam Pasal 285 KUHP yang berbunyi:

Barang siapa dengan kekerasan atau ancaman kekerasan memaksa seorang wanita bersetubuh dengan dia di luar perkawinan, diancam karena melakukan perkosaan dengan pidana penjara paling lama dua belas tahun. ${ }^{10}$

Perkosaan pada umumnya dibagi menjadi dua macam. Pertama, yaitu perkosaan yang dilakukan oleh orang yang dikenal seperti yang dilakukan oleh ayah terhadap anak, suami kepada isteri, atau yang dilakukan oleh pacar. Kedua, perkosaan yang dilakukan oleh orang yang tidak dikenal. ${ }^{11}$

\footnotetext{
${ }^{9}$ Abdul Wahid dan Muhammad Irfan, Terhadap Korban Kekerasan Seksual Advokasi atas Hak Asasi Perempuan (Bandung:Refika Aditama, 2001), h. 42

${ }^{10}$ Kitab Undang-Undang Hukum Pidana

${ }^{11}$ Suryati Romauli, Anna Vida Vindari, Kesehatan Reproduksi Buat Mahasiswi Kebidanan (Yogyakarta: Nuha Medika, 2009), h. 93-94
} 
Dengan demikian, posisi perempuan dan anak-anak perempuan di berbagai lingkungan kehidupan menjadi tidak aman dan tentram. Lidya Suryani W. dan Sri Wulandari menjelaskan bahwa perkosaan terjadi karena berbagai sebab, seperti adanya rasa dendam pelaku pada korban atau dendam terhadap wanita lain, karena pengaruh rangsangan di luar diri pelaku, seperti film atau gambar yang bernuansa pornografi, dan kerena keinginan pelaku menyalurkan dorongan seksualnya yang tidak dapat ditahannya yang didukung oleh situasi dan kondisi lingkungan, pelaku, dan korban untuk memungkinkan terjadinya perkosaan. $^{12}$

Kedekatan hubungan antara lawan jenis merupakan salah satu faktor yang cukup berpengaruh terhadap terjadinya perkosaan. Sebab di saat insteraksi antara pelaku dan korban demikian dekat, pihak perempuan kehilangan kontrol atau daya pengawasan untuk membentengi diri sedangkan pihak pelaku seperti terdorong berbuat karena mendapat kesempatan. ${ }^{13}$

Berbeda dengan pendapat di atas, Kartini Kartono mendeskripsikan bahwa latar belakang perkosaan selalu didasari dan didorong oleh nafsu seksual yang kuat disertai emosi-emosi yang tidak dewasa dan tidak mapan, biasanya disertai oleh unsur kekerasan. Menurut Abdul Wahid dan Muhammad Ifan, pendapat di atas menekankan padakegagalan pelaku mengendalian dorongan seksualnya. Hal ini terjadi karena hasrat tersebut terlalu besar dan tidak diikuti dengan cara-cara yang dibenarkan secara hukum atau agama. ${ }^{14}$

Menurut Milda Maria, perempuan korban perkosaan ditempatkan pada posisi yang problematis. Meskipun perempuan sudah menjadi korban perkosaan dan kekerasan, ia masih dipojokkan sebagai pihak yang mesti bertanggungjawab atas kasus yang menimpanya. Selama mitos kejatuhan Adam

\footnotetext{
${ }^{12} \mathrm{Abu}$ Huraerah, Child Abuse: Kekerasan Terhadap Anak (Bandung: Nuansa, 2007), h. 67

${ }^{13} \mathrm{Abu}$ Huraerah, Child, h. 70

${ }^{14} \mathrm{Abu}$ Huraerah, Child, h. 70
}

yang digoda oleh Hawa masih dipercaya dan dianggap sebagai sebuah kebenaran, maka selama itu pula perempuan akan dituduh sebagai penggoda dan karena itu laki-laki berhak memperkosanya. ${ }^{15}$

\section{Metode Penelitian}

Jenis penelitian yang digunakan adalah yuridis normatif dengan pendekatan perundang-undangan (statute approach) dan pendekatan perbandingan (comparative approach). Data penelitian diperoleh melalui penelusuran literal terhadap bahan hukum primer berupa Peraturan Perundang-Undangan meliputi Undang-Undang Nomor 1 Tahun 1974 tentang Perkawinan, Kompilasi Hukum Islam, Undang-Undang Nomor 4 Tahun 1979 tentang Kesejahteraan Anak, UndangUndang Nomor 23 Tahun 2002 tentang Perlindungan Anak, dan Undang-Undang Nomor 32 Tahun 2004 tentang Penghapusan Kekerasan Dalam Rumah Tangga.

Bahan hukum primer yang dianggap relevan mewakili fiqh, yaitu Kitab al-Fiqh 'Ala Madzahib al-Arba'ah karya Abdurahman al-Jaziri, al-Figh al-Islamy Wa Adillatuh karya Wahbah az-Zuhayly, Figh al-Sunnah karya Sayyid Sabiq, dan Bidayah al-Mujtahid wa Nihayah alMuqtashid karya Ibnu Rusyd. Bahan hukum sekunder berupa buku-buku yang berkaitan dengan perwalian, kekerasan dalam rumah tangga, dan perkosaan. Serta didukung dengan bahan hukum tersier berupa kamus.

Data dalam penelitian ini akan dianalisis menggunakan metode deskriptif komparatif dengan cara mendeskripsikan data yang diperoleh dari literatur fiqh maupun peraturan perundang-undangan yang didukung dengan referensi yang lain dipilah ke dalam katagori kemudian data-data tersebut dikomparasikan. Tidak hanya itu, hasil komparasi tersebut dianalisis secara kritis.

\section{Hasil dan Pembahasan Ruang Lingkup Perwalian}

Peraturan perundang-undangan di In-

${ }^{15}$ Milda Maria, Kekerasan Seksual Terhadap Istri (Yogyakarta: Pustaka Pesantren, 2007), h. 2 
donesia memberikan beberapa definisi yang berbeda-beda tentang wali. Hanya tiga Peraturan Perundang-Undangan yang memberikan definisi terkait dengan perwalian, Kompilasi Hukum Islam, UndangUndang Nomor 22 Tahun 2002 tentang Perlindungan Anak, dan Undang-Undang Nomor 4 Tahun 1979 tentang Kesejahteraan Anak. Sedangkan Undang-Undang Nomor 1 Tahun 1974 tentang Perkawinan tidak memberikan definisi meskipun membahas tentang perwalian.

Meskipun membahas objek hukum yang sama, yaitu anak. Terdapat perbedaan dalam ketiga definisi di atas, meliputi perbedaan subjek hukum perwalian, fungsi, dan syarat yang melekat pada objek perwalian. Undang-Undang Nomor 22 Tahun 2002 jo. Undang-Undang Nomor 4 Tahun 1979 menambahkan badanhukum (rechtspersoon) ${ }^{16}$ sebagai pelaksana perwalian. Sedangkan KHI merinci syarat-syarat anak yang diasuh oleh wali. Namun, dari ketiganya tidak menyebutkan secara eksplisit tantang kekuasaan wali dalam perkawinan.

Sedangkan dalam khazanah fiqh, baik yang dikemukakan oleh Wahbah Zuhayly maupun Sayyid Sabiq, ${ }^{17}$ wali adalah suatu ketentuan hukum yang diberikan oleh agama

\footnotetext{
${ }^{16}$ rechts persoon adalah perkumpulan-perkumpulan yang dapat menanggung hak dan kewajiban, yang bukan manusia dan dapat melakukan persetujuan, memiliki kekayaan yang terlepas dari anggotanya. Lihat di Ishaq, Dasar-Dasar Ilmu Hukum (Jakarta:Sinar Grafika,2008), h. 49

${ }^{17}$ Wahhbah Zuhayly, al-Figh al-Islamy Wa Adillatuh, Juz. IX (Damaskus:Dâr al-Fikr,2006), h. 6690; lihat juga Muhammad Sayyid Sabiq, Figh as-Sunnah, Juz II (Beirut: Dâr al-Fikr, 2006), h. 517
}

dan dapat dipaksakan kepada orang lain, seperti menguasai dan melindungi orang atau barang, bahkan memiliki kekuasaan perkawinan. Akan tetapi, ketentuan ini tidak boleh menghalangi hak-hak orang yang berada di bawah perwaliannya. Penunjukan seseorang menjadi wali harus sesuai antara kompetensi yang dimilikinya dengan kepentingan orang yang berada di bawah perwaliannya, sehingga tujuan perwalian dapat tercapai dan tidak merugikan orang yang berada di bawah perwalian.

\section{Kedudukan Wali}

Apabila mengacu dari redaksi Pasal 6 ayat (2) Undang-Undang Nomor 1 Tahun 1974 tentang Perkawinan peran orang tua (wali) dalam perkawinan tidak lagi sentral. Meskipun dalam kondisi tertentu, peran wali masih penting sekalipun hanya sebagai pihak yang memberikan pertimbangan saja. Sedangkan KHI, justru memposisikan wali sebagai salah satu rukun yang harus ada sebelum dilaksanakannya perkawinan, sebagaimana diatur dalam Pasal 14. Implikasinya, perkawinan yang tidak melibatkan wali maka perkawinan tersebut batal demi hukum. Meskipun dianggap Ketentuan ini dianggap mengembalikan posisi perempuanberadadibawahkekuasaan wali yang telah diupayakan untuk dihapus oleh Undang-Undang Nomor 1 Tahun 1974.

Wali diberikan kedudukan sentral dalam perkawinan oleh jumhur fuqaha dengan dukungan dari hadits-hadits Rasulullah saw. Berdasarkan beberapa pendapat ini ke-

\begin{tabular}{|c|c|c|}
\hline Kompilasi Hukum Islam & $\begin{array}{l}\text { Undang-Undang Nomor } \\
22 \text { Tahun } 2002\end{array}$ & $\begin{array}{c}\text { Undang-Undang Nomor } 4 \\
\text { Tahun } 1979\end{array}$ \\
\hline $\begin{array}{l}\text { Pasal } 1 \text { huruf h: Kewenangan } \\
\text { yangdiberikankepadaseseorang } \\
\text { untuk melakukan sesuatu } \\
\text { perbuatan hukum sebagai wakil } \\
\text { untukkepentingandanatasnama } \\
\text { anak yang tidak mempunyai } \\
\text { kedua orang tua atau orang tua } \\
\text { yang masih hidup tidak cakap } \\
\text { melakukan perbuatan hukum }\end{array}$ & $\begin{array}{l}\text { Pasal } 1 \text { Nomor } 5 \text { : } \\
\text { orang atau badan yang } \\
\text { dalam kenyataannya } \\
\text { menjalankan kekuasaan } \\
\text { asuh sebagai orang tua } \\
\text { terhadap anak }\end{array}$ & $\begin{array}{l}\text { Pasal } 1 \text { Nomor } 3 \text { huruf b: } \\
\text { orang atau badan yang dalam } \\
\text { kenyataannya menjalankan } \\
\text { kekuasaan asuh sebagai orang } \\
\text { tua terhadap anak }\end{array}$ \\
\hline
\end{tabular}


dudukan wali dapat diklasifikasikan sebagai berikut: Pertama, adanya wali menentukan sahnya perkawinan secara absolut. Apabila wali bagi pihak perempuan tidak ada, maka perkawinan tersebut batal demi hukum. Pendapat ini dikemukakan oleh Imam Malik dan al-Syafi'i. Kedua, ada atau tidak adanya wali tidak mempengaruhi sahnya perkawinan. pendapat ini dikemukakan oleh Imam Hanafi. Ketiga, tidak adanya wali dalam perkawinan tidak menyebabkan perkawinan batal, kedudukannya hanya sebagai perwakilan bagi calon mempelai perempuan. Imam Ahmad dan Abu Yusuf mengatakan bahwa seorang perempuan yang berakal dan telah dewasa berhak mengawinkan dirinya sendiri. Akan tetapi jauh lebih baik jika ia menyerahkan akad perkawinanya kepada walinya. Keempat, adanya wali disyaratkan bagi gadis saja. Pendapat ini seperti yang dikemukakan oleh Daud.

Menurut Ibn Rusyd, perbedaaan ini sebabkan tidak adanya ayat atau hadits yang dengan jelas mensyaratkan wali dalam pernikahan. Kehujjahan hadits-hadits yang digunakan dalam perwalian juga masih diperselisihkan keshahihannya, kecuali hadits Ibnu Abbas. Dan golongan yang tidak mensyaratkan adanya wali juga tidak memiliki dalil. ${ }^{18}$

\section{Syarat-Syarat Wali}

Undang-Undang Nomor 1 Tahun 1974 tidak memberikan syarat khusus bagi wali dalam perkawinan. Meskipun demikian, orang tua kandung diberikan hak pertama kali memberikan izin bagi perkawinan anaknya sebagaimana diatur dalam pasal 6 ayat (2) dan pasal 6 ayat (3) baru kemudian orang yang memelihara atau keluarga yang mempunyai hubungan darah dalam garis keturunan lurus ke atas yang masih hidup sebagaimana diatur dalam pasal 6 ayat (4).

Dalam menentukan kualitas seseorang yang dapat menjadi wali dalam perkawinan, KHInampaknya mengikuti nalar fiqh dengan

${ }^{18} \mathrm{Ibn}$ Rusyd, Bidayah al-Mujtahid wa Nihayah alMuqtashid, Juz. II (Surabaya: al-Hidayah,t.th), h. 6-7 menyatakan bahwa wali nikah ialah seorang laki-laki dengan syarat muslim, berakal dan baligh, sebagaimana diatur dalam Pasal 20 ayat (1). Meskipun demikian, KHI tidak mensyaratkan adanya aspek keadilan dalam diri seorang wali dalam konteks perkawinan. KHI membagi wali menjadi dua bagian, yaitu wali nasab dan wali hakim sebagaimana diatur dalam Pasal 20 ayat (2). Menariknya adalah bahwa yang diperbolehkan menjadi wali dalam perkawinan adalah laki-laki dari garis keturunan ayah bukan ibu sebagaimana diatur dalam Pasal 21 KHI.

Para fuqaha' berbeda pendapat persoalan laki-laki yang menjadi wali. Jumhur ulama' menilai bahwa kaum wanita tidak boleh mengawinkan dirinya sendiri atau orang lain. Sedangkan menurut Abu Hanifah dan Abu Yusuf wanita yang sudah dewasa dan berakal sehat berhak mengurus sendiri akad pernikahannya, baik gadis maupun janda. Meskipun demikian, menurut keduanya lebih baik mewakilkan kepada walinya demi menjaga pandangan yang tidak baik. Dalam konteks peraturan perundang-undangan di Indonesia, hanya KHI yang mensyaratkan laki-laki sebagai wali nikah, sedangkan dalam peraturan lainnya tidak disebutkan.

Para ulama' fiqh juga berbeda pendapat tentang syarat adil bagi wali. Seorang wali disyaratkan harus adil oleh ulama madzhab Syafi'i dan madzhab Hanabilah. Sedangkan Sayyid Sabiq mengatakan bahwa seorang wali tidak disyaratkan adil. Sehingga orang yang fasiq tidak kehilangan hak menjadi wali dalam perkawinan kecuali bila kefasiqannya itu melampaui batas-batas kesopanan yang berat. Ia tidak bisa menjadi wali karena tidak bisa menentramkan jiwa perempuan yang berada di bawah kekuasaannya. Syarat yang lain adalah bijaksana, ditetapkan oleh madzhab Syafi'i dan ulama' madzhab Hanabilah. Bagi ulama madzhab Hanabilah, seorang wali harus mengetahui persoalan kafaah dan kemaslahatan dalam perkawinan, tetapi tidak dalam persoalan harta. Sedangkan ulama Syafi'iyah menyatakan bahwa bijaksana berarti tidak menyia-nyiakan harta. 


\section{Perwalian Bukan Orang Tua}

Ketentuan hukum yang berkaitan dengan syarat-syarat wali bukan orang tua kandung diatur dalam Bab XI tentang Perwakilan Undang-Undang Nomor 1 Tahun 1974 dan dalam Bab XV tentang Perwalian Kompilasi Hukum Islam. Istilah Perwalian juga digunakan dalam BAB VII Undang-Undang Nomor 23 Tahun 2002. Meskipun memberikan istilah yang berbeda, substansi peraturan tentang perwalian memiliki kemiripan.

Terdapat perbedaan antara penentuan batas usia maksimal anak yang berada di bawah perwalian. Pasal 50 ayat (1) UndangUndang Nomor 1 Tahun 1974 mengatur bahwa perwalian berlaku bagi anak yang belum mencapai umur 18 (delapan belas) tahun atau belum pernah melangsungkan perkawinan, yang tidak berada di bawah kekuasaan orang tua. Sedangkan dalam Pasal 107 ayat (1) KHI dinyatakan bahwa perwalian hanya terhadap anak yang belum mencapai umur 21 tahun dan atau belum pernah melangsungkan perkawinan. Meskipun berbeda, keduanya memberikan ruang lingkup yang sama mengenai perwalian sebagaimana diatur dalam Pasal 50 ayat (2) Undang-Undang Nomor 1 Tahun 1974 Jo. Pasal 107 ayat (2) KHI yang menyatakan bahwa perwakilan itu mengenai pribadi anak yang bersangkutan maupun harta bendanya.

Sedangkan dalam Undang-Undang Nomor 23 Tahun 2002 tentang Perlindungan Anak, tidak menyebutkan batas maksimal perwalianterhadapanak,namunmemberikan ketentuan bahwa yang dimaksud dengan anak adalah seseorang yang belum berusia 18 (delapan belas) tahun termasuk anak yang masih dalam kandungan. Dalam Pasal 1 Undang-Undang Nomor 4 Tahun 1979 yang dimaksud dengan anak adalah seseorang yang belum mencapai umur 21 (dua puluh satu) tahun dan belum pernah kawin.

Penunjukan wali, baik dalam Pasal 51 ayat (1) Undang-Undang Nomor 1 Tahun 1974 dan pasal $108 \mathrm{KHI}$ dapat dilakukan melalui surat wasiat orang tua kandung si anak. Selain itu, wali sedapat-dapatnya diambil dari keluarga anak tersebut atau orang lain yang sudah dewasa, berpikiran sehat, adil, jujur dan berkelakuan baik sebagaimana diatur dalam 107 ayat (4) KHI jo. Pasal 51 ayat (2) Undang-Undang Nomor 1 Tahun 1974. Perbedaannya, Undang-Undang Nomor 1 Tahun 1974 memperbolehkan penunjukan wali dengan lisan dan penunjukan itu dilakukan di hadapan 2 (dua) orang saksi. Sedangkan KHI tidak memberikan ketentuan tentang saksi namun memperluas subjek hukum dengan menambah unsur badan hukum.

Dalam Pasal 33 Undang-Undang Nomor 23 Tahun 2002 tentang Perlindungan Anak disebutkan bahwa pemberlakukan ketentuan wali bukan orang tua dengan beberapa alasan seperti orang tua anak tidak cakap melakukan perbuatan hukum, tidak diketahui tempat tinggal atau keberadaannya. Seperti halnya KHI, subjek hukum perwalian boleh orang atau badan hukum yang memenuhi persyaratan. Selain itu, penunjukan wali bukan orang tua melibatkan lembaga pengadilan. Pemindahan pemeliharaan anak dari orang tua kandung kepada orang lain dalam Pasal 57 ayat (2) Undang-Undang Nomor 39 Tahun 1999 dilakukan bahwa berdasarkan putusan pengadilan dengan alasan kedua orang tua telah meninggal dunia atau karena suatu sebab yang sah tidak dapat menjalankan kewajibannya sebagai orang tua.

Dalam ketentuan fiqh disebutkan bahwa seorang wali, harus sempurna kecakapannya. Seseorang dapat dikatakan cakap jika memenuhi beberapa unsur, seperti baligh, berakal dan merdeka. Selain itu, harus ada persamaan agama antara seorang wali dengan orang yang di bawah kekuasaannya. Persamaan latar belakang agama ini juga diatur dalam Pasal 33 ayat (3) Undang-Undang Nomor 23 Tahun 2002 tentang Perlindungan Anak yang menyatakan bahwa wali yang ditunjuk sebagaimana dimaksud dalam ayat (2) agamanya harus sama dengan agama yang dianut oleh anak. 


\section{Pencabutan Kekuasaan Wali Alasan Pencabutan}

Adapun alasan yang dikemukakan dalam Pasal 49 ayat (1) Undang-Undang Nomor 1 Tahun 1974 tentang Perkawinan dalam hal pencabutan kekuasaan orang tua sebagai wali, yaitu melalaikan kewajibannya terhadap anaknya dan berkelakuan buruk sekali. Ketentuan ini juga berlaku untuk wali bukan orang tuakandung sebagaimana diatur dalam pasal 53 ayat (1). Meskipun demikian, yang dimaksud dengan "kekuasaan" dalam Pasal ini tidak termasuk kekuasaan wali dalam perkawinan. Hal ini menunjukkan bahwa kekuasaan wali dalam perkawinan bersifat mutlak dan tidak memperdulikan tentang ketentuan wali yang berkelakuan buruk sekali serta kondisi psikologis korban perkosaan oleh wali, dalam hal ini adalah anak.

Sedangkan dalam Pasal 109 KHI dijelaskan bahwa pencabutan kekuasaan wali karena ia pemabuk, penjudi, pemboros, gila dan atau melalaikan atau menyalahgunakan hak dan wewenangnya sebagai wali. Ketentuan tentang alasan pencabutan wali lebih rinci dalam KHI meskipun tidak menjelaskan tentang pencabutan kekuasaan wali dalam perkawinan.

Dalam Pasal 10 Undang-Undang Nomor 4 Tahun 1979 tentang Kesejahteraan Anak dinyatakan bahwa pencabutan kekuasaan orang tua karena ia melalaikan tanggungjawabnya dalam mewujudkan kesejahteraan anak baik secara rohani, jasmani maupun sosial sehingga mengakibatkan timbulnya hambatan dalam pertumbuhan dan perkembangan anak. Dalam Pasal tersebut dijelaskan tentang dampak yang timbul dari perbuatan wali yang menjadi alasan pencabutan kekuasaannya terhadap anak.

Dalam Pasal 30 ayat (1) Undang-Undang Nomor 23 Tahun 2002 tentang Perlindungan Anak dinyatakan bahwa kekuasaan orang tua terhadap anak dapat dicabut apabila melalaikan kewajibannya, mengasuh, memelihara, mendidik, dan melindungi anak, me- numbuhkembangkan anak sesuai dengan kemampuan, bakat, dan minatnya, dan mencegah terjadinya perkawinan pada usia anak-anak.

Dalam Pasal 59 Undang-Undang Nomor 39 Tahun 1999 tentang Hak Asasi Manusia (HAM) dijelaskan bahwa pada asasnya setiap anak berhak untuk tidak dipisahkan dari orang tuanya secara bertentangan dengan kehendak anak sendiri, kecuali jika ada alasan dan aturan hukum yang sah yang menunjukkan bahwa pemisahan itu adalah demi kepentingan terbaik bagi anak. Dalam keadaan sebagaimana dimaksud dalam ayat (1), hak anak untuk tetap bertemu langsung dan berhubungan pribadi secara tetap dengan orang tuanya tetap dijamin oleh Undang-undang.

Sedangkan dalam konteks fiqh, menurut Sayyid Sabiq seorang wali yang fasiq tidak kehilangan hak menjadi wali dalam perkawinan kecuali bila kefasiq-annya itu melampaui batas-batas kesopanan yang berat. Ia tidak bisa menjadi wali karena tidak bisa menentramkan jiwa anak yang berada di bawah kekuasaannya. Salah satu aspek yang berkaitan dengan hal ini adalah keadilan. Menurut Wahbah Zuhaily, aspek ini berkaitan dengan istiqomah dalam menjalankan ibadah. Seorang wali dilarang melakukan perbuatan maksiat seperti zina, mabuk, berjudi atau perbuatan buruk lainnya. Logikanya, bentuk-bentuk maksiat yang bersifat ordinary saja bisa mengakibatkan hilangnya kelayakan menjadi wali, bagaimana mungkin perkosaan dan penganiayaan terhadap anak perempuan yang berada di bawah perwaliannya yang dianggap sebagai extraordiray crime tidak bisa digunakan sebagai alasan pencabutan kekuasaan wali.

\section{Mekanisme Pencabutan Kekuasaan Wali}

Dalam Pasal 49 Undang-Undang Nomor 1 Tahun 1974 tentang Perkawinan dijelaskan bahwa pencabutan kekuasaan orang tua atau wali atas permintaan orang tua yang lain, 
keluarga anak dalam garis lurus ke atas dan saudara kandung yang telah dewasa atau pejabat yang berwenang.

Pasal 31 Undang-Undang Nomor 23 Tahun 2002 tentang Perlindungan Anak mengklasifikasikan para pihak yang dapat mengajukan permohonan pencabutan kuasa asuh sebagai berikut: Pertama, Salah satu orang tua, saudara kandung, atau keluarga sampai derajat ketiga. Kedua, apabila kelompok pertama tidak dapat melaksanakan fungsinya, maka pencabutan kuasa asuh orang tua dapat juga diajukan oleh pejabat yang berwenang atau lembaga lain yang mempunyai kewenangan untuk itu. Orang yang diberikan hak mengajukan permohonan pencabutan diperluas dalam Undang-Undang ini, dengan menambahkan pihak keluarga sampai derajat ketiga dan lembaga lain yang berwenang.

Pasal 109 KHI dinyatakan bahwa pencabutan hak perwalian seseorang atau badan hukum dan pemindahannya kepada pihak lain dilakukan atas permohonan kerabatnya. Ketentuan dalam KHI ini lebih sempit dari pada peraturan dalam Peraturan PerundangUndangan lainnya.

\section{Cara Pencabutan Kekuasaan Wali}

Pasal 49 Undang-Undang Nomor 1 Tahun 1974 tentang Perkawinan dinyatakan bahwa pencabutan kekuasaan wali melalui keputusan Pengadilan. Hal serupa juga dinyatakan dalam Pasal 10 ayat 3 UndangUndang Nomor 4 Tahun 1979 tentang Kesejahteraan Anak. Hanya saja istilah yang digunakan berbeda, yaitu ditetapkan dengan keputusan hakim. Dalam Pasal 109 KHI juga dinyatakan bahwa Pengadilan Agama dapat mencabut hak perwalian seseorang atau badan hukum dan memindahkannya kepada pihak lain.

Pasal 30 Undang-Undang Nomor 23 Tahun 2002 tentang Perlindungan Anak dinyatakan bahwa ada dua mekanisme yang diberikan dalam pencabutan kekuasaan orang tua, yaitu dilakukan pengawasan terlebih dahulu kemudian pencabutan. Tindakan pengawasan terhadap orang tua atau pencabutan kuasa asuh tersebut dilakukan melalui penetapan pengadilan. Dalam ketentuan ini yang dicabut bukan kekuasaan wali nikah melainkan kuasa asuh.

\section{Pelimpahan Kekuasaan Wali}

Pasal 10 Undang-Undang Nomor 4 Tahun 1979tentang Kesejahteraan Anakmenyatakan bahwa untuk menjalankan fungsi sebagai orang tua dapat ditunjuk orang atau badan sebagai wali. Sedangkan dalam Pasal 26 ayat (2) Undang-Undang Nomor 23 Tahun 2002 tentang Perlindungan Anak dinyatakan bahwa dalam hal orang tua tidak ada, atau tidak diketahui keberadaannya, atau karena suatu sebab, tidak dapat melaksanakan kewajiban dan tanggung jawabnya, maka kewajiban dan tanggung jawab dapat beralih kepada keluarga, yang dilaksanakan sesuai dengan ketentuan peraturan perundang-undangan yang berlaku. Selain itu, dalam Pasal 51 Undang-Undang yang sama dijelaskan bahwa pengadilan melalui penetapannya dapat menunjuk orang perseorangan atau lembaga pemerintah/masyarakat untuk menjadi wali bagi yang bersangkutan.

Dalam Pasal 109 KHI (Kompilasi Hukum Islam) dinyatakan bahwa kekuasaan sebagai wali bagi anak dapat dipindahkan kepada kepada pihak lain atas permohonan kerabatnya. Pihak lain yang dimaksud dalam pasal ini merujuk pada Pasal 107 ayat (4) KHI yang menyatakan bahwa wali sedapatdapatnya diambil dari keluarga anak tersebut atau orang lain yang sudah dewasa, berpikiran sehat, adil, jujur dan berkelakuan baik, atau badan hukum. Ketentuan ini memiliki kemiripan dengan Pasal 51 ayat (2) Undang-Undang Nomor 1 Tahun 1974 tentang Perkawinan yang menyatakan bahwa wali sedapat-dapatnya diambil dari keluarga anak tersebut atau orang lain yang sudah dewasa, berpikiran sehat, adil, jujur dan berkelakuan baik. Akan tetapi, dalam Undang-Undang Nomor 1 Tahun 1974 ten- 
tang Perkawinan tidak menyebutkan unsur badan hukum.

\section{Implikasi Pasca Pencabutan}

Meskipun orang tua telah dicabut kekuasaan kewaliannya, dalam Pasal 49 UndangUndang Nomor 1 Tahun 1974 tentang Perkawinan dijelaskan bahwa keduanya masih berkewajiban untuk memberi pemeliharaan kepada anak tersebut. Kemudian, pencabutan itu berlaku untuk waktu yang tertentu, namun tidak dijelaskan berapa lama batas pencabutan tersebut.

Dalam Pasal 10 ayat (2) Undang-Undang Nomor 4 Tahun 1979 tentang Kesejahteraan Anak dinyatakan bahwa pencabutan kuasa asuh tidak menghapuskan kewajiban orang tua yang bersangkutan untuk membiayai, sesuai dengan kemampuannya, penghidupan, pemeliharaan, dan pendidikan anaknya.

Implikasi hukum pasca pencabutan kekuasaan orang tua atau wali yang diatur dalam Pasal 32 Undang-Undang Nomor 23 Tahun 2002 Perlindungan Anak lebih lengkap dari kedua Undang-Undang di atas. Dalam pasal ini setidaknya memuat tiga hal pokok yaitu, tidak memutuskan hubungan darah antara anak dan orang tua kandungnya, tidak menghilangkan kewajiban orang tuanya untuk membiayai hidup anaknya, dan batas waktu pencabutan. Persamaan dari ketiga

\section{DAFTAR PUSTAKA}

Huraerah, Abu. 2007. Child Abuse: Kekerasan Terhadap Anak.Bandung: Nuansa

Huraerah, Abu. 2006. Perjuangan Berat Perempuan Indonesia Menggapai Keadilan di Tengah Berbagai Keterpurukan, (Online), (http://www.lbh-apik.or.id/ catahu\%202006.htm, diakses tanggal 11 Juni 2011)

Ishaq. 2008. Dasar-Dasar Ilmu Hukum. Jakarta:Sinar Grafika

Kitab Undang-Undang Hukum Pidana

Kompilasi Hukum Islam disebarluaskan melalui Instruksi Presiden Nomor 1 Tahun 1991 peraturan ini adalah tidak hilangnya kewajiban terhadap anak dan batas waktu.

\section{Kesimpulan}

Terdapat persamaan antara fiqh munakahat dan peraturan perundang-undangan dalam menentukankelayakan wali untukperkawinan terkait dengan latar belakang agama dan aspek kedewasan. Namun, terdapat perbedaan antara keduanya, seperti tidak masuknya aspek keadilan dan kebijaksanaan yang berlaku pada setiap perwalian dalam figh dalam KHI. Namun, dalam menentukan siapa yang berhak menjadi wali dalam perkawinan KHI mengikuti nalar fiqh yang terkesan patriakhis. Sedangkan UndangUndang Nomor 1 Tahun 1974 memberikan kedudukan yang sama antara ayah dan ibu dalam perkawinan.

Pencabutan kekuasaan wali dalam konteks peraturan perundang-undangan hanya berkaitan dengan kuasa asuh orang tua melalui mekanisme di pengadilan. Pencabutan ini tidak belaku untuk kekuasaan wali dalam perkawinan. Meskipun demikian, fiqh munakahat masih memberikan peluang pencabutan kekuasaan wali dalam perkawinan jika wali sudah tidak kredibel dan memiliki cacat kepribadian, seperti melakukan kekerasan bahkan perkosaan terhadap orang yang berada di bawah perwaliannya.

LBH APIK. 2005. Pemiskinan Perempuan dan Upaya Setengah Hati Negara dalam Menegakkan Hak Asasi Perempuan, (Online), (http://www.lbh-apik.or.id/ catahu\%202005.htm, diakses tanggal 11 Juni 2011)

Maria, Milda. 2007. Kekerasan Seksual Terhadap Istri.Yogyakarta:Pustaka Pesantren

Mufidah Ch., 2008. Psikologi Keluarga Islam Berwawasan Gender. Malang:UINMalang Press

Rusyd, Ibn. Bidayah al-Mujtahid wa Nihayah al-Muqtashid, Juz. II.Surabaya: alHidayah 
124 I de Jure, Jurnal Syariah dan Hukum, Volume 3 Nomor 2, Desember 2011, hlm. 114-124

Romauli, Suryati Vindari, Anna Vida. 2009. Kesehatan Reproduksi Buat Mahasiswi Kebidanan.Yogyakarta: Nuha Medika

Tarida, Sahat. 2011. Kekerasan Seksual dalam Catatan Tahunan Komnas Perempuan.2011.(Online),(http://www. komnasperempuan.or.id/2011/08/ kekerasan-seksual-dalam-catatantahunan-komnas-perempuan-tahun2011/, diakses tanggal 08 September 2011)

Wahid, Abdul dan Irfan,Muhammad.2001. Terhadap Korban Kekerasan Seksual
Advokasi atas Hak Asasi Perempuan. Bandung:Refika Aditama

Zuhayly,Wahbah. 2006. al-Figh al-Islamy Wa Adillatuh, Juz. IX.Damaskus:Dâr alFikr

\section{Peraturan Perundang-Undangan}

Undang-Undang Nomor 22 Tahun 2002 tentang Perlindungan Anak LN. Tahun 2002 Nomor 109

Undang-Undang Nomor 4 Tahun 1979 tentang Kesejahteraan Anak LN. Tahun 1979 Nomor 32 